\title{
Sub-daily extreme events distribution and changes in Northeastern Brazil in the 20th century
}

\author{
R. Basso ${ }^{1}$, D. Allasia ${ }^{2}$, R. Tassi ${ }^{2}$, and D. M. Bayer ${ }^{3}$ \\ ${ }^{1}$ Civil Engineering/PPG Engenharia Civil, University of Santa Maria, Santa Maria, Brazil \\ ${ }^{2}$ Sanitary and Environmental Engineering Department/PPG Engenharia Civil, University of Santa Maria, \\ Santa Maria, Brazil \\ ${ }^{3}$ Sanitary and Environmental Engineering Department/PPG Engenharia Civil/PPG Engenharia Ambiental, \\ University of Santa Maria, Santa Maria, Brazil \\ Correspondence to: R. Basso (basso.raviel@gmail.com) and D. Allasia (dallasia@gmail.com)
}

Received: 23 April 2015 - Accepted: 23 April 2015 - Published: 11 June 2015

\begin{abstract}
The regional analysis of extreme hydrological events is connected with the availability of a dense network of rainfall data that is absent or inaccessible in Brazil, especially for sub-daily information. In engineering, extreme events rainfall information is represented by intensity-duration-frequency (IDF) relationships which are the most commonly used tools in water resources engineering for planning and design. Even if the sub-daily information that is included in the relationships is not available, the extreme rainfall information rest in the fundamentals of the IDF. This paper analyzes spatial distribution and track changes in sub-daily precipitation over Northeastern (NE) Brazil. Precipitation was estimated from IDF relationships information in Brazil based in rainfall measured from 1920's to 1950's (but still used in engineering projects) and information from the last half of the 20th century obtained from several IDFs gathered from municipalities' manuals, local symposia and books in many cases not easily obtainable. Results showed an intensification of extreme events in recent years, especially in shorter duration rainfall (less than $12 \mathrm{~h}$ ). Hourly rainfall is bigger in almost all the Brazilian region, but especially in littoral and Northern portion, however, 12 and $24 \mathrm{~h}$ rainfall exhibit increases in the North, but, lower values in the Southern half of the region in concordance with flood changes reported by Milly et al. (2005). Analyzing the ratio between 1 and $24 \mathrm{~h}$ rainfall is possible to confirm its increase in all the region, with up to $35 \%$ in some areas. These results were able to show insight of sub-daily extreme events changes during 20th century in NE Brazil were previous reports were not found. The results also alerts for the necessity of engineering projects review, as outdated information is still being used for design purposes.
\end{abstract}

\section{Introduction}

Extreme rainfall events are responsible for erosion, damages to agriculture, ecology and infrastructure, and inclusive damage to human activities. Consequently, the knowledge of the relationship between intensity, duration and frequency (IDF) becomes crucial for the design of hydraulic structures that prevent these problems. However, due to the small network of pluviographs and faulty data, among other problems, IDFs are scarce or have serious problems in many developing countries (Koutsoyiannis et al., 1998).

This is the case of Brazil, were IDF are scarce and there is only one national study developed by Pfafstetter (1957) using around 20 years of data prior to 1955 and republished in 1982 without modifications. This publication is still a reference for the development of engineering and agronomy projects. Pfafstetter (1957) obtained the IDF in only 98 sites scattered throughout the continental size Brazil, with most of the pluviographs located in the South and Southeast of the country.

In this light, designers were obliged to perform extrapolations from normally distant pluviographs without real acknowledge of the information representativity. With the purpose of reducing the error associated with extrapolations, Torrico (1974), using the same data as Pfafstetter (1957), came to the conclusion that Brazil had eight heavy rainfall 


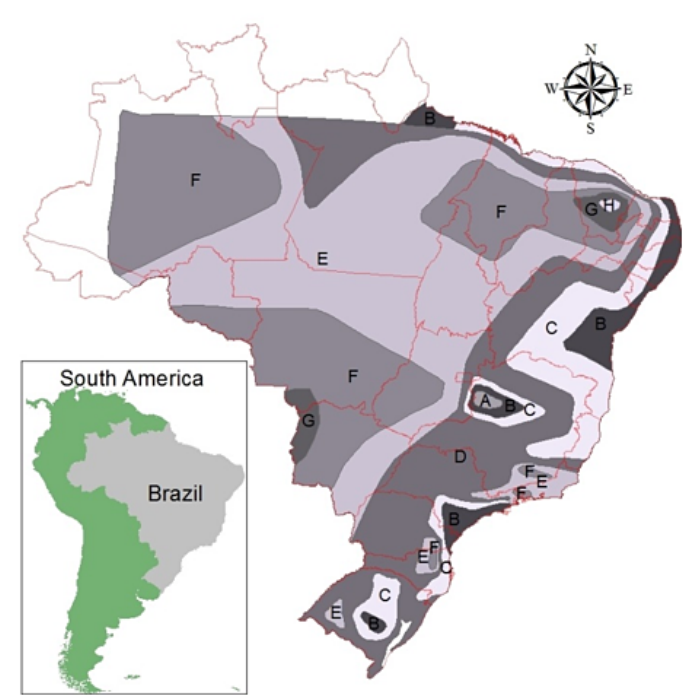

a)

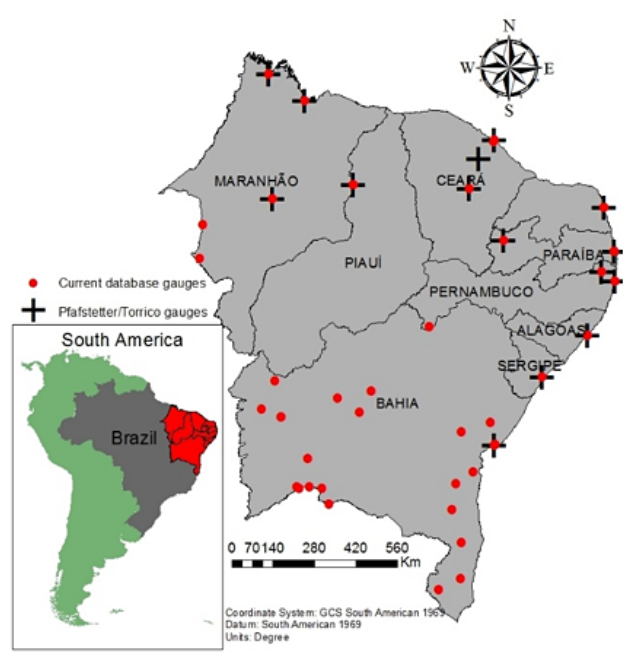

b)

Figure 1. (a) Map of Equal Rainfall Zones (adapted from Torrico, 1974). (b) Location of rain gauges used by Pfafstetter (pre-1955 data) and the newer database gauges.

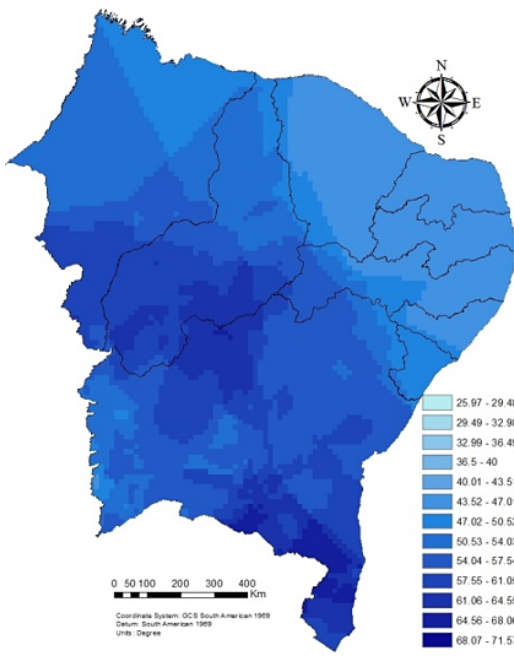

a) $a$

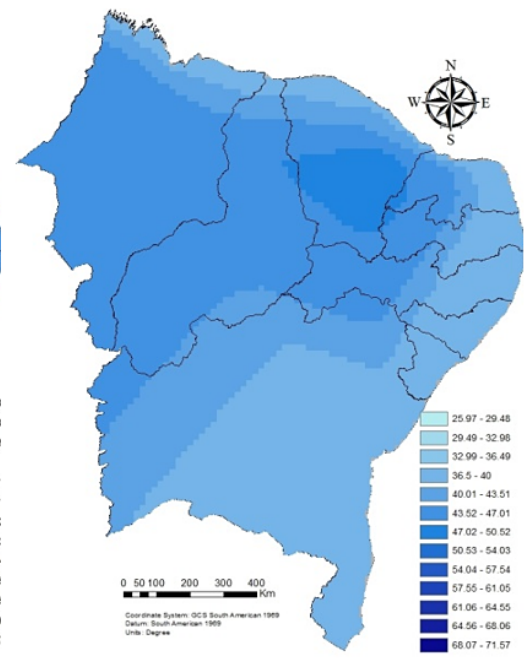

b) $a$

Figure 2. (a) r1h24h values in percentage determined in this study. (b) r1h24h based on the results of Torrico (1974) and Pfafstetter (1957).

distinctive regions (identified by $\mathrm{A}-\mathrm{H}$ in Fig. 1a) where rainfall behaved similarly (named in Portuguese as isozonas). Within these regions, Torrico (1974) concluded that Pfafstetter (1957) information could be transferred without problems and departing from the more abundant daily rainfall pluviometers, the information could be disaggregated in subdaily rainfall for different durations.

In the absence of better information, even today, almost 40 years after its production, and based on information collected prior to 1955 , the methodology proposed by Torrico (1974) is still used for the estimation of extreme rainfall in several engineering projects. Among those projects, could be mentioned Gameleira's Dam in Piauí (Carvalho, 2005), Access to the Astronomical observatory of Itaparica (NORCONSULT, 2011), the metropolitan ring road of Porto Alegre (ODEBRECHT, 2009). The recommendation for the use of isozonas is also in the Municipal Sanitation Master Plan of Florianópolis, known as the Brazilian state's capital city with the highest Human Development Index score (MPB, 2012), as well as in others plans and projects in the country.

In the last years, changes in heavy rainfall intensity have been reported for various regions around the world. For example, Iwashima and Yamamoto (1993) analyzed daily rainfall data from 1890 to 1980 at 55 Japanese stations and found 

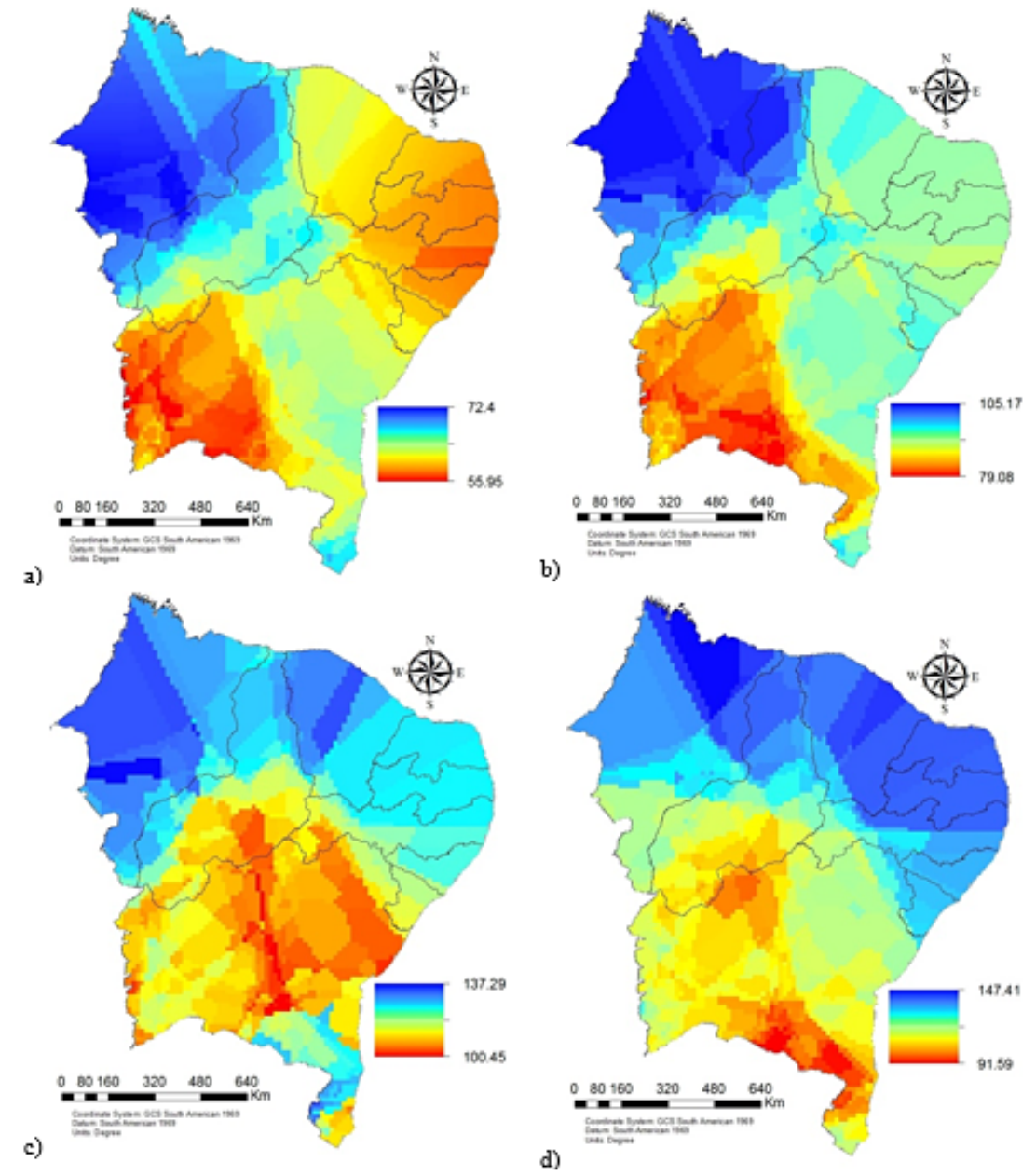

Figure 3. Precipitation amount based on the IDF's gathered during this study for $1 \mathrm{~h} \mathrm{(a),} 4 \mathrm{~h}(\mathbf{b}), 12 \mathrm{~h}$ (c), and $24 \mathrm{~h}$ (d) duration.

that several stations recorded their highest, 2nd highest or 3rd highest rainfall event in more recent decades. Comprising seven stations located in the northeastern Italy, Brunetti et al. (2001) observed for the period 1920-1998, a negative trend in the number of wet days associated with an increasing in the contribution of heavy rainfall events to total precipitation. Karl et al. (1995) found an increasing trend in those rainfall events exceeding $50.8 \mathrm{~mm}^{-1}{ }^{-1}$ over the USA. Nicholls and Kariko (1993) investigated rainfall data at five representative stations in east Australia from 1910 to 1988. The authors found an increasing in rainfall which was mainly due to more rain days rather than higher rainfall intensity.

In Brazil, Groisman et al. (2005) and Marengo (2009) identified changes in intensity and frequency in rainfall extremes in the last 60 years in the Southeastern portion. Specifically in Northeastern Brazil $\left(\mathrm{NE}_{\mathrm{B}}\right)$, a region known for its low quality data (Marengo, 2006) reports by Hastenrath and Greischar (1993), Marengo et al. (1998) and IPCC (2001) indicate a positive trend in rainfall, however, without statistical significance. In turn, Milly et al. (2005) analyzing changes in flows, found an increasing of up to $30 \%$ in flows in the North of this region while a decreasing of up to $20 \%$ in the southern part of the Northeast Brazil when comparing the period 1971-1998 against 1900-1970. In the $\mathrm{NE}_{\mathrm{B}}$ region, in 2004, in just a month was registered rainfall of up to $1000 \mathrm{~mm}$ with disastrous consequences while the mean annual rainfall is around $550 \mathrm{~mm}$ (Greenpeace 2006).

Given this scenario, this study regionalizes and compares the data presented by Pfafstetter (1957) and Torrico (1974), against the most recent IDFs for the Northeast of Brazil (Fig. 1b). These IDFs are obtained from many sources ranging from symposia to municipalities publications. The comparison permitted the visualization of the changes in the behavior of the extreme rainfall in the Northeastern Region of Brazil.

\section{Data and methods}

A research in municipalities' manuals, local symposia and books (i.g., Silva et al., 2002; Denardin and Freitas, 1982; 

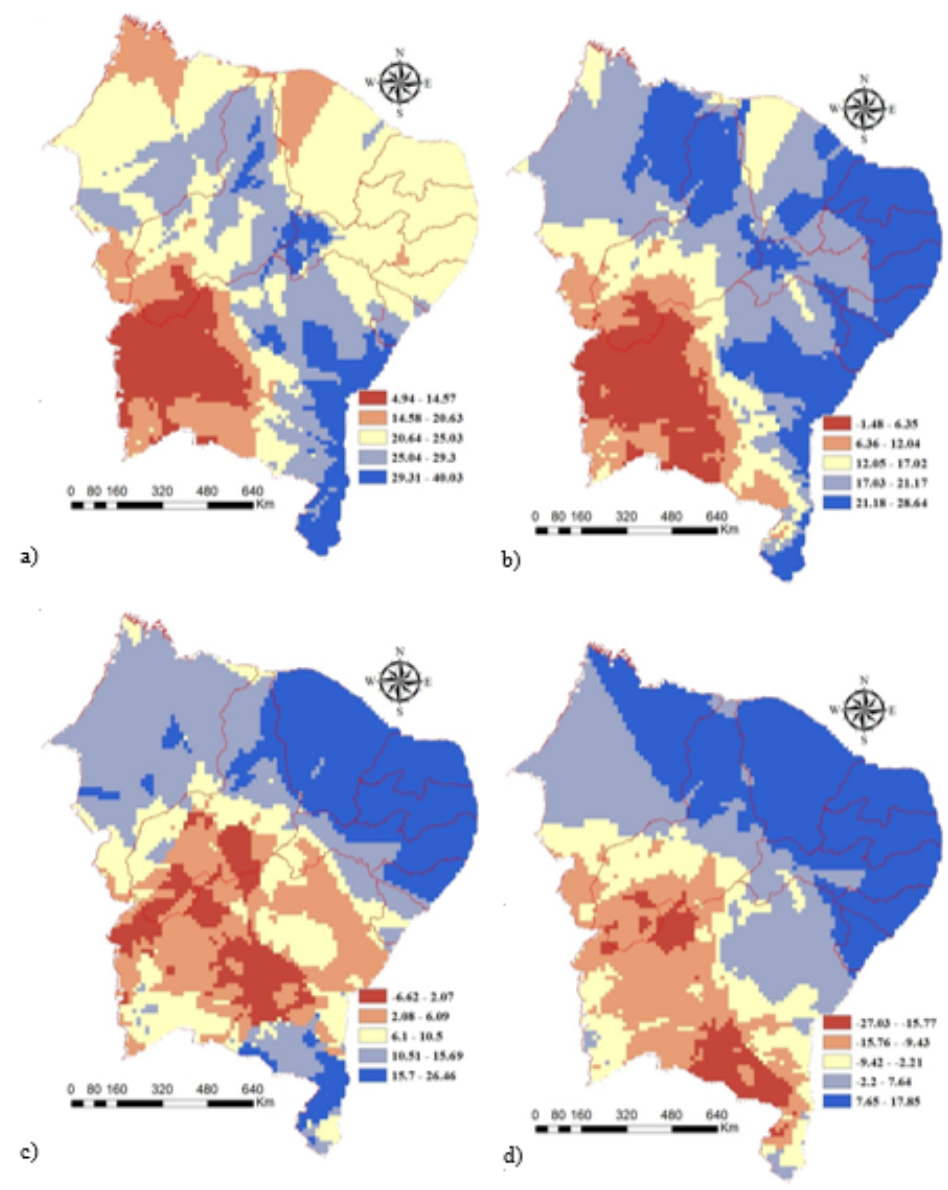

Figure 4. Comparison in percentage between the IDF's gathered during this study and Pfafstetter (1957) for (a) $1 \mathrm{~h}$, (b) $4 \mathrm{~h}$, (c) $12 \mathrm{~h}$ and (d) $24 \mathrm{~h}$ duration. Positive values indicate highest rainfall in the newer rainfall set.

Fragoso, 2004, among others) resulted in a database of almost 60 IDF's equations. In many cases these IDFs were not easily available and only found after a time consuming investigation. Following a quality checks, 51 were selected to be compared against Torrico (1974) or Pfafstetter (1957) data (Fig. 1b). The comparison was accomplished for a return period of 10 years which is customarily used for urban drainage projects in Brazil (Bertoni and Tucci, 1993). Furthermore, Chen (1983) and Hershfield and Wilson (1958) indicated that the results does not vary with different returns periods and some testing accomplished with return periods 2 and 100 years also confirmed this hypothesis.

It should be noted that newer IDF data spans from different periods. Several stations are from 1988 to 1998, some of them from 1975 to 1995 and for some of them has been impossible to determine the exact data period, but the available rainfall data and testimonials strongly suggest series of about 15 years within 1970's-1990's. Due to the reason that is the only data available to get an insight into sub-daily rainfall information, it was used in this study, always taking care and making a cross-checking with existing publications as validation.

By using GIS tools the rainfall heights with several duration $(1,4,12$, and $24 \mathrm{~h})$ obtained from older and newer IDFs were interpolated by ordinary kriging. The interpolated rainfall from the different periods were compared sideby-side determining percent change between them. In the case of the relationship between $1 \mathrm{hr}$ rainfall and $24 \mathrm{~h}$ rainfall $(\mathrm{r} 1 \mathrm{~h} 24 \mathrm{~h})$, the interpolated values obtained from newer information were simply compared against original Torrico (1974) regional values.

\section{Results and discussion}

A comparison side-by-side between of $\mathrm{r} 1 \mathrm{~h} 24 \mathrm{~h}$ obtained from current IDF and Pfafstetter (1957) information (Fig. 2a and b) showed that hourly rainfall that was $40 \%$ of $24 \mathrm{~h}$ rainfall in the first half of 20th century increased to almost $70 \%$, indicating the intensification of $1 \mathrm{~h}$ extremes. A softer decrease is observed in the North of the region (Ceará, Rio 
Grande do Norte and Paraíba States) with a reduction of up to $13 \%$ (Fig. 2c).

The rainfall amounts within 1, 4, 12 and $24 \mathrm{~h}$ duration were also analyzed, in order to have a better view of rainfall climatology. In Fig. 3a-d the rainfall amounts based on the newer data shows that rainfall in the region increases northwards (up to $50 \%$ ), however, with slight differences in distribution according to the analyzed duration. As Pfafstetter (1957) data shows similar rainfall patterns, it could be concluded that the rainfall mean pattern was captured by the methodology.

However, both databases shows different amount of rainfall for each duration. In the case of 1 hour rainfall, the newer IDF's based information shows an increment compared to Pfafstetter's (1957) in all the region. The increase could be up to $40 \%$ in the central region. On the other hand, the rise for $4 \mathrm{~h}$ rainfall is less pronounced, with almost no increase in the Southwest and the largest values in the North of the Region (Fig. 4). The larger duration rainfall (12 and $24 \mathrm{~h}$ ) (Fig. 4c and d) shows contrasting signals, with decrease in total rainfall in the Southern region and increase in the North regions. The results for $24 \mathrm{~h}$ are similar to the changes in flows reported by Milly et al. (2005), and as this duration is closer to the time of concentration of the basins could be considered as a validation of results.

\section{Conclusions}

This paper analyzed spatial distribution and changes in subdaily and daily precipitation over Northeastern (NE) Brazil. Precipitation was estimated from IDF relationships information in Brazil based on rainfall measured from 1920's to 1950's (but still used in engineering projects) and information from the last half of the 20th century obtained from several IDFs gathered from municipalities' manuals, local symposia and books in many cases not easily obtainable. Results showed an intensification of extreme events in recent years, especially in shorter duration rainfall (less than $12 \mathrm{~h}$ ). Hourly rainfall is bigger in almost all the region, but especially in littoral and Northern portion, however, 12 and $24 \mathrm{~h}$ rainfall exhibit increases in the North, but, lower values in the Southern half of the region in concordance with flood changes reported by Milly et al. (2005).

Although some of the data presented in this study should be cautioned due to lacks of information about the construction of the IDF itself, results were consonant with existing publications providing an indirect validation. Even with these limitations the findings were able to show insight of sub-daily extreme events changes during 20th century in NE Brazil, were previous reports were not found. The results also warns about changes in extreme events, especially for shorter duration that are often the cause of urban drainage disasters alerting for the necessity of engineering projects review.
Acknowledgements. Raviel Basso thanks CAPES/Brasil for the Fellowship that permitted this research.

\section{References}

Bertoni, J. C. and Tucci, C. E. M.: Precipitaion, in: Hydrology - Science and application, edited by: Tucci, C. E. M., ABRH/EDUSP, Porto Alegre, 177-242, 1993 (in Portuguese).

Brunetti, M., Maugeri, M., and Nanni, T.: Changes in total precipitation, rainy days and extreme events in northeastern Italy, Int. J. Climatol., 21, 861-871, 2001.

Carvalho, N. L.: Gameleira's Dam - Basic Engineering Project of the dam and complementary structures, Piauí State, Final Report, available at: http://pt.scribd.com/doc/77289098/, last access: 20 December 2014, May 2005 (in Portuguese).

Chen, C. L.: Rainfall intensity-duration-frequency formulas, J. Hydraul. Eng.-ASCE, 109, 1603-1621, 1983.

Denardin, J. E. and Freitas, P. L.: Fundamental characteristic of rainfall in Brazil, Pesquisa Agropecuária Brasileira, Brasília, 17, 1409-1416, 1982.

Fragoso, C. R.: Regionalização da Vazão Máxima Instantânea com base na Precipitação de Projeto, ReRH: Revista Eletrônica de Recursos Hídricos, IPH/UFRGS, Porto Alegre, 1, 5-13, 2004 (in Portuguese).

Greenpeace: Semi-arid, in: Climate changes, life changes: How global warming is already affecting Brazil, prepared by Greenpeace-Brazil, São Paulo, 24-28, 2006 (in Portuguese).

Groisman, P. Y., Knight, R. W., Easterling, D. R., Karl, T. R., Hegerl, G. C.,and Razuvaev, V. N.: Trends in intense precipitation in the climate record, J. Climate, 18, 1326-1350, 2005.

Hastenrath, S. and Greischar, L.: Further work of Northeast Brazil rainfall anomalies, J. Climate, 6, 743-758, 1993.

Hershfield, D. M. and Wilson, W. T.: Generalizing of RainfallIntensity-Fequency Data, in: Publication 43 of the International Association of Scientific Hydrology, General Assembly of Toronto, 3-4 September 1957, 499-506, Gentbrugge, Belgium, 1958.

IPCC (Intergovernmental Panel on Climate Change): Climate Change 2001: Impacts, Adaptation and Vulnerability, Contribution of Working Group II to the Third Assessment Report of the Intergovernmental Panel on Climate Change, edited by: McCarthy, J. J., Canziani, O. F., Leary, N. A., Dokken, D. J., and White, K. S., Cambridge University Press, Cambridge, UK, and New York, USA, 1032 pp., 2001.

Iwashima, T. and Yamamoto, R.: A statistical analysis of the extreme events: long-term trend of heavy daily precipitation, J. Meteorol. Soc. Jpn., 71, 637-640, 1993.

Karl, T. R., Knight, R. W., and Plummer, N.: Trends in highfrequency climate variability in the twentieth century, Nature, 377, 217-220, 1995.

Koutsoyiannis, D., Kozonis, D., and Manetas, A.: A mathematical framework for studying rainfall intensity-duration-frequency relationships, J. Hydrol., 206, 118-135, 1998.

Marengo, J. A.: Interdecadal and Long term variability, in: Global climate change and its effects on biodiversity: Characterization of the current climate and climate change definition to the Brazilian territory over the 21 st century, Brasília, Ministry of Environment, 38-57, 2006 (in Portuguese). 
Marengo, J. A.: Future Change of Climate in South America in the Late 21st Century: the CREAS Project, AGU AS Newsletter, 3, p. 5, 2009.

Marengo, J. A., Tomasella, J., and Uvo, C.: Long-term streamflow and rainfall fluctuations in tropical South America: Amazonia, eastern Brazil and Northwest Peru, J. Geophys. Res., 103, 17751783, 1998.

Milly, P. C. D., Dunne, K. A., and Vecchia, A. V.: Global pattern of trends in streamflow and water availability in a changing climate, Nature, 438, 347-350, 2005.

MPB Engenharia: Municipal integrated sanitation Master Plan, PMISB, Prefeitura Municipal de Florianópolis, 2009, available at: www.pmf.sc.gov.br, last access: 10 January 2015, 2012 (in Portuguese).

Nicholls, N. and Kariko, A.: East Australian rainfall events: interannual variations, trends, and relationships with the Southern Oscillation, J. Climate, 6, 1141-1152, 1993.
NORCONSULT, Projetos e Consultoria Ltda: Project Engineering officer for paving of access to the Observatory of the municipality of Itacuruba, Pernambuco, v. 1, Relatório do Projeto Básico, 2011 (in Portuguese).

ODEBRECHT: Feasibility study and modeling for deploying East segment of the Metropolitan ring road, Through the Public Private Partnership grant, 2009, available at: http://www.cecom.rs. gov.br, last access: 10 January 2015, 2009.

Pfafstetter, O.: Heavy rainfalls in Brazil: Relationship between rainfall, duration and frequency rainfall, Departamento Nacional de Obras e Saneamento, Rio de Janeiro, 426 pp., 1957 (in Portuguese).

Silva, D. D., Gomes Filho, R. R., Pruski, F. F., Pereira, S. B., and Novaes, L. F.: Intense rainfalls in Bahia State, Revista Brasileira de Engenharia Agrícola e Ambiental, Campina Grande, Brasil, 6, 362-367, 2002 (in Portuguese).

Torrico, J. J. T.: Hydrological practices, Transcom, Rio de Janeiro, Brasil, 120 pp., 1974. 